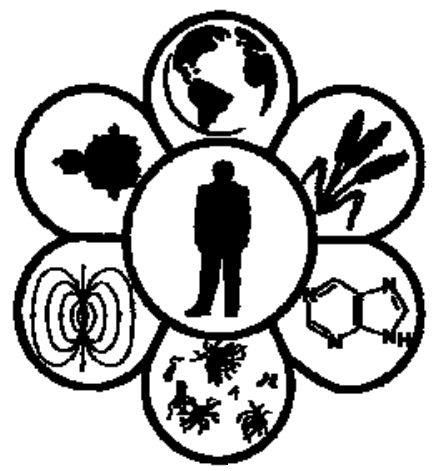

Вісник Дніпропетровського університету. Біологія. Медицина Vìsnik Dnìpropetrovs'kogo unìversitetu. Serìa Bìologîa, medicina

Visnyk of Dnipropetrovsk University. Biology, medicine. 2013. 4(1)

ISSN 2310-4155

www.medicine.dp.ua

УДК: 614.715:616-056.3-084:(477.63)

\title{
Аеропалінологічний спектр м. Дніпропетровськ як основа профілактики сезонної алергії
}

\author{
В.В. Родінкова
}

\author{
Вінницький національний медичний університет імені М.I. Пирогова, Вінниия, Украӥна
}

\begin{abstract}
Наведено результати першого для Дніпропетровська спостереження за спектром алергенного пилку у повітрі та змінами його концентрації упродовж сезону. Основні пилкопродуценти у досліджуваному місті - амброзія, рослини роду щириця та родини лободових, кропива дводомна, рослини роду полин, представники родини складноцвіті, роду тополя, родин злакові, конопляні та роду береза. Перша, весняно-літня палінаційна хвиля, яка зазвичай спостерігається в інших містах України, у Дніпропетровську мало виражена. Результатом роботи стало створення календаря пилкування алергенних рослин для досліджуваного міста. Цей календар потребує постійного оновлення через зміну факторів довкілля, що впливають на розповсюдження природних алергенів.
\end{abstract}

Ключові слова: аеробіологія, календар пилкування, сезонна алергія, Дніпропетровськ

\section{Airborne pollen spectrum of Dnipropetrovsk city as a basis of hay fever control}

\author{
V.V. Rodinkova \\ Vinnytsia National Pirogov Memorial Medical University, Vinnytsia, Ukraine
}

Hay fever is important allergenic complain with number of patients rising year by year. Ukraine holds the leading positions in Europe in accordance with pollinosis morbidity. Therefore, it's important to determine regional pollen spectrum for all five climatic and geographical zones of the country having certain variety of plants' allergens. There are just a few cities with a constant pollen monitoring carried out in Ukraine. They are Vinnytsia, Kyiv, Odessa and Lviv. Palynological range of other Ukrainian cities remains unknown or poorly studied. Dnipropetrovsk - Ukrainian city with location in the Central part of the country in the Steppe zone - isn't exception as well. Thus, the aim of our study was to determine the pattern of airborne pollen distribution and pollen calendar creation for the city of Dnipropetrovsk. Pollen count obtained at Vinnytsia National Pirogov Memorial Medical University (VNMU) by Aerobiology Research Group. Study was held in 2010 from the $17^{\text {th }}$ of March till the $20^{\text {th }}$ of October on daily basis employed volumetric methods using the Burkard trap. It stands on the roof of the Dnipropetrovsk Municipal hospital at 20 meters of a relative height above ground. The air samples were sent by currier mail on weekly basis from Dnipropetrovsk to Vinnytsia for the research term. 51 pollen types were determined during the study period. The aeropalinological research was done for the Dnipropetrovsk at first. Study was conducted in association with the European Aeroallergen Network (EAN). The EAN tools and the software package "Statistica 5.5" were used for data statistical analysis. The study showed prevalence of the airborne herbal pollen types in Dnipropetrovsk. The "weeds : trees" pollen ratio was « $88: 12 »$. Most abundant pollen rain (59\% of total annual pollen count) was produced by Ambrosia. The second position with 6\% was held by Amaranthus / Chenopodiaceae pollen group and Urtica dioica pollen. Artemisia and other representatives of Asteraceae constituted of 5\% each. The most abundant tree pollen rain (4\% from total annual count) was produced by the Populus species. Betula pollen was the next having up 2\% of annual pollen rain in Dnipropetrovsk. As can be seen, the first arboreal spring-summer pollination wave was not massive in Dnipropetrovsk. It was represented by Populus, Betula, Acer, Fraxinus, Quercus, Ulmus, Pinus, Juglans pollen spread in the end of March, whole April and the first weeks of May mostly. However, the second wave was intensively seen from the mid of July till the mid of October. Important airborne pollen producing taxa were Artemisisia, Ambrosia, Asteraceae, Chenopodiaceae, Urtica, Plantago, Polygonaceae pollen at that time. Important airborne pollen allergens of Poaceae family (grasses) held the $7^{\text {th }}$ position in the total annual pollen rain and were recorded between two pollination waves from the mid of May till the end of June mostly. The worst period for the patients was associated with the Betula, Acer and Quercus pollination from $13^{\text {th }}$ of April till the mid of May and with Ambrosia and Artemisia pollination from $28^{\text {th }}$ of July, till September, 30 . The present airborne

Вінницький національний медичний університет імені М.І. Пирогова, вул. Пирогова, 56, м. Вінниця, 21018, Украйна. Tел.: +38050-549-96-56.E-mail: vikarodi@gmail.com

Vinnitsa National Pirogov Memorial Medical University, Pirogov str., 56, Vinnitsa, 21018, Ukraine.

Tel.: +38050-549-96-56. E-mail: vikarodi@gmail.com 
pollen calendar should be considered while diagnosing the hay fever symptoms in sensitive patients. It's important to continue the pollen count and control in Dnipropetrovsk due to constant changing of climatic and anthropogenic conditions impacting the pollen production and release.

Keywords: aerobiology; pollen calendar; hay fever; Dnipropetrovsk

\section{Вступ}

Одним із чинників довкілля, що рік за роком справляє все помітніший вплив на здоров'я чутливих до нього верств населення, $є$ пилок алергенних (особливо анемофільних) рослин, який переноситься вітром у великих кількостях і викликає спалахи сезонної алергії у певний період року. Галузь науки, що вивчає розповсюдження пилку та спор грибів у повітрі, визначається як аеробіологія (Kagen et al., 2005). Для контролю за якістю та кількістю перенесеного у повітрі пилку у світі створено ряд систем і моніторингових програм, що об'єднують зусилля науковців цілих континентів (Sofiev and Bergmann, 2013). Наприклад, Свропейська аероалергенна мережа (European Aeroallergen Network, EAN), метою якої $\epsilon$ здійснення пилкового аеромоніторингу, була створена у 1976 році під егідою Медичного університету Відня (Австрія) і наразі включає понад 6000 пунктів спостереження за пилком у всій Європі (Jager et al., 2012). 32009 року до цієї мережі входить і пункт спостереження Вінницького національного медичного університету (ВНМУ), де аналіз пилкового спектра повітря ведеться з 1999 року.

За час існування мережі у більшості європейських міст установлено наявність двох хвиль палінації: весняно-літньої, представленої пилком дерев, та літньоосінньої, представленої пилком трав (Sofiev and Bergmann, 2013). Багатосезонні аеропалінологічні дослідження, проведені європейськими (Myszkowska et al., 2011; Buters et al., 2012; Galan and Dominguez, 2012) та українськими вченими (Prikhodko, 2008; Rodinkova, 2012), також показали з року у рік зростаючу у зв'язку з глобальним потеплінням кількість пилку у повітрі та зміну сезонної динаміки палінації рослин (Deaka et al., 2013). Зокрема, для такого важливого європейського аероалергену як пилок берези (Betula) встановлено дворічний цикл пилкування, а також - тенденцію до більш раннього початку палінаційного періоду дерев як у Свропі, так і в Україні (Grewling et al., 2012; Rodinkova and Kremenska, 2011). Ці та інші (Melgar et al., 2012; Piotrowska and Kubik-Komar, 2012) отримані дані щодо поступової зміни аеропалінологічного спектра у часі залежно від погодних і кліматичних умов (Kizilpinar et al., 2010) дали змогу говорити про обмежений термін валідності будь-якого календаря пилкування аероалергенів, складеного для певної місцевості (Sofiev and Bergmann, 2013). При цьому доведено регіональність пилкового спектра рослин, викликану як факторами довкілля, так і антропогенними чинниками, що зумовлюють наявність тих чи інших насаджень у межах певного ландшафту, а, отже, формують і видовий склад флори даної місцевості (Bikakci et al., 2010; Oh et al., 2010; Della Torre et al., 2010; Molina et al., 2013).

Тому для контролю за такими чинниками та для попередження можливих ризиків виникнення спалахів сезонної алергії у багатьох країнах став розвиватись сервіс для пацієнтів щодо прогнозування концентрації пилку в атмосфері, здебільшого - на безкоштовній для пацієнтів основі (Tormo-Molina, 2008; Hilaire et al., 2012;
Piotrowska, 2012; Rapielko and Lipiec, 2012). Важливим також стало питання оцінки алергенності самого пилку та інструментального визначення наявності у ньому факторів, що спричиняють сенсибілізацію, і визначення їх кількості (Fernandes-Gonzalez et al., 2008; Castro et al., 2011; Weger et al., 2011; Buters et al., 2012). Спроби такої оцінки проводяться як за кордоном, так і в Україні (Rodinkova et al., 2012). За показниками захворюваності населення на поліноз Україна посідає одне 3 чільних місць у Європі. Тому наша країна, що має п'ять кліматогеографічних зон із певною відмінністю рослинних алергенів (Puhlik et al., 2012), потребує проведення аеромоніторингу в усіх цих зонах для встановлення регіональних особливостей палінологічного спектра алергенних рослин. На даний час відомі результати багаторічного спостереження за пилком анемофільних рослин у Вінниці, Києві, Запоріжжі та Львові (Rodinkova, 2012). Палінологічний спектр інших українських міст залишається маловивченим або не вивченим взагалі. Не винятком 3 останньої групи є й Дніпропетровськ, розташований у Центральній частині України, у степовій природній зоні.

Тому мета нашого дослідження - з'ясувати характер розповсюдження алергенного пилку у повітрі Дніпропетровська $з$ установленням часу та інтенсивності палінації рослин і створенням на його основі регіонального календаря пилкування алергенних рослин.

\section{Матеріал і методи досліджень}

Робота виконана у лабораторії аероалергенних методів досліджень Вінницького національного медичного університету, на базі сьомої клінічної лікарні м. Дніпропетровськ за підтримки фармацевтичої фірми Merck Sharp and Doum (MSD) та Імунологічного дослідного інституту Нової Англії IRINE (США) у 2010 році. Проби повітря відбирали стандартним волюметричним методом за допомогою пробовідбірника ударного типу «Буркард» (Burkard trap) (Lanzoni, 2009; Kagen et al., 2004).

Прилад розташований на даху міської клінічної лікарні № 7 по вул. Шмідта (рис. 1). Розташування приладу на даху приміщень, не затінених іншими високими будинками поруч, дає змогу зібрати не лише локальні, а й міграційні фракції пилку у даному регіоні (Mozo, 2011).

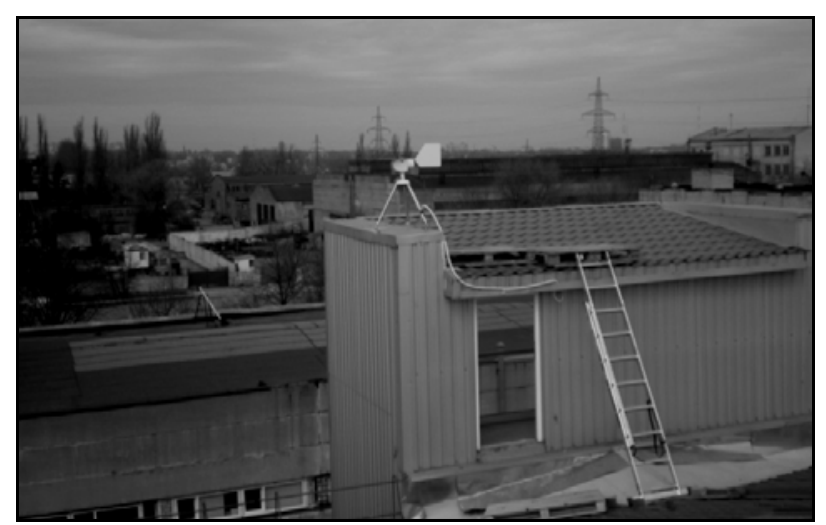

Рис. 1. Прилад Burkard Sporewatch на даху міської клінічної лікарні № 7 у м. Дніпропетровськ 
Дослід проведено 17.03-20.10.2010 р. у цілодобовому режимі. На барабан зі стрічкою «Мелінекс» (Melinex tape), що керувався годинниковим механізмом і робив один оберт у приладі впродовж одного тижня, були відібрані 32 щотижневі зразки повітря. Перед відбором зразків стрічку «Мелінекс» вкривали липкою субстанцією на основі желатин-гліцерину з додаванням фенолу. Після відбору проб барабан зі зразками у герметично закритому металевому боксі разом із протоколом його заміни, де відзначались дата, час, погодні умови впродовж тижня, особливості роботи приладу, надсилали до Вінниці службою кур'єрської доставки. У лабораторії аероалергенних методів дослідження ВНМУ стрічку, зняту з барабана, поділяли на 7 рівних фрагментів, що відповідали одній добі спостереження. Із кожного фрагмента виготовляли один мікроскопічний зразок, який фіксували на предметному склі желатином і фарбували основним фуксином. Використання основного фуксину - індикатора та спеціальної фарби для рослинної сировиини, що вибірково забарвлює біологічний матеріал, полегшує ототожнення пилкових зерен (п. з.) та їх підрахунок.

Дослідження вмісту та концентрації пилку у зразках атмосферного повітря проведене на системі цифрового аналізу зображення VIDAS-386 (Kontron Elektronik, Hiмеччина) із використанням мікроскопа Axioscop (Zeiss, Німеччина), обладнаного високочутливою мікрофотографічною камерою COHU-7922. Для аналізу та підрахунку п. з., в основному, використано збільшення $400^{x}$. У такий спосіб отримано та проаналізовано 224 зразки. Упродовж сезону палінації ідентифіковано п. з. 51 морфологічного типу, що належали відповідній кількості рослин різних родин, родів та видів. Це дослідження стало першим відомим аеропалінологічним спостереженням, проведеним у Дніпропетровську.

У зв'язку з тим, що підрахунок п. з. на поверхні всього скла забирає багато часу, для того, щоб швидко отримувати актуальну інформацію, зазвичай аналізується тільки певний відсоток площі зразка (Galán et al., 2007). Область, обрана для ідентифікації, становила як мінімум $10 \%$ площі всього скельця, згідно з вимогами робочої групи Європейського аеробіологічного товариства (EAS), яка розробляє вимоги до контролю якості проведення аеробіологічних досліджень (Sofiev and Bergmann, 2013). Ідентифікацію п. з. проводили методом трьох горизонтальних транссект (Galán et al., 2007) за визначником аероалергенів, виданим представниками Національного алергологічного бюро Американської академії алергіï, астми та імунології (National Allergy Bureau of the American Academy of Allergy, Asthma \& Immunology (AAAAI)) (Kagen et al., 2004), а також за програмою Pollen Identification Key (Sulmont, 2008) Французької національної мережі аеробіологічного моніторингу (RNSA), де зазначається також рівень алергенності пилку. В окремих випадках використано атласи пилку та спор Європейської частини СРСР (Kuprijanova and Aleshina, 1972; Kuprijanova and Aleshina, 1978). Пилок ідентифікували до таксономічної категорії виду (в окремих випадках), роду (найчастіше) або родини залежно від морфології окремого п. з. (Kagen et al., 2004; Sulmont, 2008). При обробці даних щодо характеру пилкування визначених палінологічних груп рослин використано програмний пакет Statistica 5.5 та потужності Європейської аероалергенної мережі (EAN), побудовані на базі програмного пакета SPSS. Крім того, для розробки вебресурсу використано системи, які перебувають у вільному доступі, як, наприклад, Tapestry - для вебінтерфейсу, Spring Framework - для з'єднання окремих частин ресурсу в єдине ціле, PostgreSQL - для підтримання баз даних, Apache POI - для читання та збереження файлів електронних таблиць, JFreeChart - для створення графіки та Apache Tomcat - як вмістилище вебдодатків (European Pollen Information, 2012).

Тривалість палінаційного періоду рослин кожного роду та родини визначали вирахуванням відсотка від загальної кількості зібраних за сезон п. з. певної палінологічної категорії. За нормами, прийнятими у EAN (European Pollen Information, 2012), сезон пилкування рослини починається того дня, коли кількість ії пилку у повітрі становить $1 \%$ загальної суми зібраних упродовж року п. з. Закінченням сезону вважається день, коли кількість зібраного за сезон пилку досягає 95\%. Піком пилкування вважається найвище значення концентрації п. з. у кубометрі повітря, зафіксоване для описуваної палінологічної категорії упродовж сезону. Згідно з правилами EAN, визначається лише один пік пилкування для кожної аеропалінологічної категорії упродовж сезону. Він відповідає найвищій зареєстрованій концентрації п. з. даного таксона у повітрі. Пороговим значенням концентрації п. з., що, як припускається, може бути клінічно значущою для пацієнтів, була обрана концентрація у 15 п. 3./ $\mathrm{M}^{3}$ для представників трав'янистих рослин, крім полину, де помірною вважається концентрація, вища за 25 п. з./ $\mathrm{M}^{3}$ у зв'язку з відносно невисокою алергенністю пилку представників названого роду. Така ж порогова концентрація $\left(25\right.$ п.з./ $\left.\mathrm{M}^{3}\right)$ вважається клінічно значущою для представників деревних рослин, крім тополі, пилок якої розглядається як малоалергенний. Тому межею помірної концентрації п. з. тополі $є$ така, що перевищує 50 п. з./ $\mathrm{M}^{3}$. Цей поріг концентрації залежить від групи алергенності, до якої належить рослина (Frenz, 1995; Sulmont, 2008). Деревні рослини, як правило, характеризуються у рази масивнішою палінацією, ніж трав'янисті. Тому концентрації п. з., які для них $є$ клінічно значущими, також $\epsilon$ підвищеними порівняно з концентраціями, які беруться до уваги при аналізі можливості виникнення полінозу до пилку трав'янистих рослин.

\section{Результати та їх обговорення}

Аналіз особливостей пилкового спектра Дніпропетровська показав, що у повітрі цього міста переважав пилок трав (табл. 1). Співвідношення внеску арбореальної та трав'янистої палінофлори в інтенсивність пилкового дощу склало $88: 12$ на користь трав.

Загальна кількість п. з. усіх пилкопродуцентів, зібраних упродовж сезону пилкування, склала 24724. 59\% палінологічного спектра Дніпропетровська (табл. 1) припадає на пилок амброзії (Ambrosia). Упродовж сезону ідентифікували 14532 п. з. цієї рослини. На другому місці із часткою 6\% - рослини групи Amaranthus spp. / Chenopodiaceae («рід щириця / родина лободові»), які об'єднуються в одну аеропалінологічну категорію через морфологічну нерозрізненість п. з. (1462 п. з. зібрані упродовж сезону). Так само 6\% пилкового спектра Дніпропетровська становила частка п. 3. кропиви дводо- 
мної (Urtica dioica). Упродовж сезону ідентифіковано 1377 п. з. цієї рослини. На відсоток менше (5\% від загальної масивності пилкування або 1319 п. з.) становила частка пилку полину (Artemisia spp.). Решта рослин родини айстрових (Asteraceae) також внесли 5\% до загальної маси пилкового дощу у Дніпропетровську (1195 п. з.).

Наймасивнішу палінацію серед дерев (1319 п. з., але тільки 4\% загальної кількості зерен, зібраних у Дніпропетровську за сезон), мала тополя (Populus spp.) - найінтенсивніший серед усіх деревних пилкопродуцентів. Другим наймасовішим за пилкопродукцією представником деревної флори у Дніпропетровську (2\% та 483 п. 3., зібрані за сезон) була береза (Betula spp.). Проте вона посідала лише дев'яту позицію за інтенсивністю формування пилкового дощу у місті. На сьомій позиції, відділяючи березу від лідера палінації тополі, були злакові (Poaceae) - 3\% і 652 п. 3., зібрані упродовж сезону
2010 року. На восьмій сходинці розмістились представники родини конопляні (Cannabaceae) - конопля рудеральна (Cannabis ruderalis) та хміль (Humulus lupulus) - із часткою у $2 \%$ та 518 п. 3. за рік (див. табл. 1). Нетипово високе десяте місце в аеропалінологічному спектрі Дніпропетровська посіла шовковиця (Morus spp.). Ïї частка становила 2\% або 407 п. 3., зібраних за сезон. Приблизно однакову із шовковицею кількість зібраних за сезон п. 3. (385) і частку (2\%) мав подорожник. Решта таксонів, що потрапили до двадцятки рослин із наймасовішим пилкуванням, отримали в аеропалінологічному спектрі лише 1\%, або менше від загальної кількості зібраних за сезон п. з. Це (у порядку зменшення внеску в інтенсивність пилкового дощу над Дніпропетровськом) рослини родини гречкових (Polygonaceae), клен (Acer spp.), ясен (Fraxinus spp.), дуб (Quercus spp.), сосна (Pinus spp.), в'яз (Ulmus spp.), волоський горіх (Juglans regia), вільха (Alnus spp.) та граб (Carpinus sp.).

Таблиця 1

Характер пилкування найактивніших представників аероалергенної флори м. Дніпропетровськ (2010 р.)

\begin{tabular}{|c|c|c|c|c|c|c|c|c|c|}
\hline № & Аеробіологічна категорія & $\begin{array}{c}\text { Сума } \\
\text { визначених } \\
\text { за сезон } \\
\text { п. } 3 . \\
\end{array}$ & $M \pm \sigma$ & $\begin{array}{c}\text { \% від за- } \\
\text { гальної } \\
\text { кількості } \\
\text { п. з. за рік }\end{array}$ & $\begin{array}{c}\text { Дата } \\
\text { початку } \\
\text { сезону }\end{array}$ & $\begin{array}{c}\text { Дата } \\
\text { настання } \\
\text { піка }\end{array}$ & $\begin{array}{c}\text { Пікова } \\
\text { концент- } \\
\text { рація, } \\
\text { п. з./м }{ }^{3}\end{array}$ & $\begin{array}{c}\text { Дата } \\
\text { закінчення } \\
\text { сезону }\end{array}$ & $\begin{array}{c}\text { Кількість } \\
\text { днів із п. } 3 . \\
\text { у повітрі }\end{array}$ \\
\hline 1 & Амброзія (Ambrosia sp.) & 14532,0 & $59,3 \pm 176,7$ & 59 & 12.08 & 02.09 & 1491,0 & 25.09 & 102 \\
\hline 2 & $\begin{array}{l}\text { Щириця / Лободові } \\
\text { (Amaranthus spp. / Chenopodiaceae) }\end{array}$ & 1462,0 & $6,0 \pm 13,4$ & 6 & 29.07 & 24.08 & 104,0 & 25.09 & 115 \\
\hline 3 & Кропива дводомна (Urtica dioica) & 1377,0 & $5,6 \pm 11,9$ & 6 & 16.06 & 17.06 & 84,0 & 31.08 & 127 \\
\hline 4 & Полин (Artemisia spp.) & 1319,0 & $5,4 \pm 12,2$ & 5 & 22.07 & 01.08 & 80,0 & 04.10 & 99 \\
\hline 5 & Айстрові (Asteraceae) & 1195,0 & $4,9 \pm 16,7$ & 5 & 13.08 & 01.09 & 143,0 & 26.09 & 112 \\
\hline 6 & Тополя (Populus alba) & 983,0 & $4,1 \pm 28,5$ & 4 & 08.04 & $13 / 04$ & 402,0 & 20.04 & 39 \\
\hline 7 & Тонконогові (Роасеае) & 652,0 & $2,7 \pm 6,1$ & 3 & 14.05 & 21.06 & 45,0 & 26.09 & 137 \\
\hline 8 & Конопляні (Cannabaceae) & 518,0 & $2,1 \pm 7,8$ & 2 & 29.07 & 13.08 & 73,0 & 31.08 & 67 \\
\hline 9 & Береза (Betula spp.) & 483,0 & $2,0 \pm 6,6$ & 2 & 18.03 & 20.04 & 60,0 & 12.05 & 48 \\
\hline 10 & Шовковиця (Morus spp.) & 407,0 & $1,7 \pm 8,5$ & 2 & 03.05 & 10.05 & 74,0 & 19.05 & 25 \\
\hline 11 & Подорожник (Plantago spp.) & 385,0 & $1,3 \pm 4,2$ & 2 & 03.06 & 17.08 & 34,0 & 25.08 & 93 \\
\hline 12 & Гречкові (Polygonaceae) & 248,0 & $1,0 \pm 2,0$ & 1 & 03.05 & 18.06 & 13,0 & 12.09 & 99 \\
\hline 13 & Клен (Acer spp.) & 213,0 & $0,9 \pm 4,3$ & 1 & 08.04 & 20.04 & 44,0 & 27.04 & 26 \\
\hline 14 & Ясен (Fraxinus spp.) & 207,0 & $0,8 \pm 3,0$ & 1 & 14.04 & 20.04 & 26,0 & 05.05 & 31 \\
\hline 15 & Дуб (Quercus spp.) & 199,0 & $0.7 \pm 3,8$ & 1 & 28.04 & 03.05 & 43,0 & 12.05 & 25 \\
\hline 16 & Сосна (Pinus spp.) & 167,0 & $0,6 \pm 2,5$ & 1 & 09.05 & 28.05 & 28,0 & 01.08 & 52 \\
\hline 17 & В'яз (Ulmus spp.) & 135,0 & $0,6 \pm 2,6$ & 1 & 01.04 & 13.04 & 24,0 & 19.04 & 25 \\
\hline 18 & Волоський горіх (Juglans regia) & 121,0 & $0,5 \pm 2,6$ & $<1$ & 03.05 & 11.05 & 22,0 & 12.05 & 13 \\
\hline 19 & Вільха (Alnus spp.) & 76,0 & $0,3 \pm 1,0$ & $<1$ & 17.03 & 13.04 & 7,0 & 21.04 & 30 \\
\hline 20 & Граб (Carpinus sp.) & 45,0 & $0,2 \pm 0,6$ & $<1$ & 17.03 & 25.03 & 5,0 & 08.05 & 30 \\
\hline
\end{tabular}

Перша, весняна хвиля пилкування, що зазвичай спостерігається в інших містах України та представлена деревами, у Дніпропетровську була мало вираженою (див. табл. 1). Основним весняним пилкопродуцентом у місті була тополя, пік палінації якої досяг високого значення (402 п. з./ $\left.\mathrm{M}^{3}\right) 13$ квітня, але пилок цієї рослини, як уже зазначалось і як установили наші дослідження (Rodinkova et al., 2012), не є алергенним. Концентрації пилку інших представників арбореальної палінофлори жодного разу не перетнули межу у 100 п. 3./ M $^{3}$. Наступний після тополі пік (74 п. 3./ $\left.\mathrm{M}^{3}\right)$ мала шовковиця. Він спостерігався 10 травня. За даними літератури (Sulmont, 2008), алергенність пилку шовковиці $є$ нульовою за п'ятибальною шкалою.

Сезонний максимум пилкування берези 3 помірною, проте клінічно значущою концентрацією (60 п. 3./ $\left.\mathrm{M}^{3}\right)$ спостерігався 20 квітня. П. з. берези мають алергенність «5» за п’ятибальною шкалою.

Наступним за висотою сезонного піка був клен, максимум якого зафіксований в один день із піком берези $\left(44\right.$ п. 3./ $\left.{ }^{3}\right)$. Але алергенність пилку цієї рослини становить 0-1 бал. На одиницю менший (43 п. 3./ $\left.\mathrm{M}^{3}\right)$ пік пилкування дуба. Його максимум зафіксований 3 травня. Алергенність п. 3. дуба - 3 з 5 балів (Sulmont et al., 2008). Решта дерев мали піки 3 низькими концентраціями. Це Fraxinus (рослина, що має малоалергенний пилок, із піком у 26 п. з. $/ \mathrm{M}^{3}$, зафіксованим 20 квітня) та Pinus (iз піком у 26 п. з./ $/ \mathrm{M}^{3}$ неалергенного пилку, зареєстрованим 28 травня). Пік малоалергенного пилку в’яза (24 п. 3./ м $\left.^{3}\right)$ припав на 13 квітня. У той самий день спостерігались піки вільхи 3 низькою концентрацією $\left(7\right.$ п. 3./ $\left.\mathrm{m}^{3}\right)$ та ліщини звичайної (10 п. 3./ $\left.\mathrm{M}^{3}\right)$. Ще нижчий сезонний максимум граба $\left(5\right.$ п. 3./ $\left.\mathrm{M}^{3}\right)$ спостерігався 25 березня. 
У зв'язку з малою інтенсивністю пилкування дерев у Дніпропетровську клінічно значущими можуть бути лише дні 3 максимально високими зареєстрованими концентраціями п. з. дерев у атмосфері міста. Це період 320 квітня по 3 травня (коли зафіксовано максимум для берези та клена) до максимуму пилкування дуба (третя декада квітня та перша декада травня).

Неінтенсивне весняне пилкування деревних рослин збіглося з малоінтенсивною палінацією злакових трав із родини тонконогових (Роасеае). Сезон активності злаків (див. табл. 1, 2) почався 14 травня, а закінчився 29 вересня (тривав 135 діб). Це був найдовший період пилкування, притаманний рослинам Дніпропетровська в описуваному сезоні. П. з. Роасеае ідентифіковано в атмосфері міста 137 діб, тобто сезон був дуже щільним, майже без інтервалів. Пік палінації злаків із помірною концентрацією 45 п. з./ $\mathrm{m}^{3}$ зафіксовано 21 червня. Раніше за злакові трави (3 травня) розпочали сезон рослини родини гречкових - 131 доба, до 12 вересня. Проте внесок до інтенсивності пилкового дощу над Дніпропетровськом гречкових малий (див. табл. 1). У свій сезон п. з. гречкових ідентифіковано у повітрі з численними інтервалами упродовж 99 діб, а пік мав низьку концентрацію (13 п. 3./ $\left.\mathrm{M}^{3}\right)$.

Друга хвиля пилкування (літньо-осіння, представлена П. з. трав'янистих рослин) почалась у Дніпропетровську 16 червня 3 пилкування кропиви (тривало до 31 серпня - 76 діб). Пилок кропиви ідентифіковано у повітрі міста упродовж 127 діб. Максимум палінації кропиви спостерігався на добу пізніше за початок статистично вирахуваного сезону палінації (17 червня). Наступним у літньо-осінню хвилю (22 липня) пилкування почав полин. Його максимум із високою концентрацією (80 п. 3./ $\mathrm{M}^{3}$ ) спостерігався 1 серпня (див. табл. 1), а закінчився 4 жовтня. Через тиждень після полину (29 липня) почався сезон реєстрації п. з. групи «рід щириця / родина лободові» (Amaranthus spp. / Chenopodiaceae). Річний максимум цієї групи, палінація якої у місті була другою за масивністю після амброзії, спостерігався 24 серпня.
Він мав високу концентрацію (104 п. 3./ $\left.\mathrm{M}^{3}\right)$. Закінчився сезон 25 вересня (див. табл. 1) і тривав 58 діб. Сезон був нещільним: п. з. щириці та лободових реєструвались у повітрі Дніпропетровська упродовж 115 діб. В один день iз полином (29 липня) зафіксовано початок пилкування рослин родини конопляні. Їх палінація була доволі інтенсивною, адже у загальній структурі активності аероалергенів конопляні посіли восьме місце. Проте, за даними Sulmont (2008), пилок представників родини не $\epsilon$ алергенним. Високим (73 п. з./M $\left.\mathrm{M}^{3}\right)$ був і пік, що спостерігався 13 серпня. Усього п. з. родини спостерігалися у повітрі Дніпропетровська 3 інтервалами упродовж 67 діб, а статистично визначений сезон тривав 33 доби. Ще одним аероалергеном, який у місті на Дніпрі посідав незвично для нього високу, п'яту сходинку у загальній структурі основних пилкопродуцентів, були представники родини айстрових (Asteraceae), за винятком п. з. амброзії та полину. Сезон активності цих трав, що мають помірну алергенність (3 бали за п'ятибальною шкалою) (Buters et al., 2012), почався 13 серпня та тривав до 26 вересня (44 доби). Пікова концентрація п. 3. цього аероалергену 3 високим показником (143 п. з./ $\left.\mathrm{M}^{3}\right)$ спостерігалась 1 вересня. У цілому п. з. айстрових реєструвались у повітрі Дніпропетровська упродовж 112 діб.

Незважаючи на присутність у повітрі п. з. інших пилкопродуцентів, 312 серпня до 29 вересня основною складовою повітряного контенту та головним алергенним фактором для жителів Дніпропетровська стала амброзія. Її пилкування було найінтенсивнішим серед усіх представників аеропалінофлори цього пункту спостереження. Воно тривало з 20-х чисел липня до кінця часу спостереження у жовтні (див. табл. 1), хоча сезон, разом із клінічно значущими концентраціями, почався 12 серпня і тривав до 25 вересня (див. табл. 2). Сезонний максимум із надвисокою та найбільшою для українських міст концентрацією пилку амброзії (1491 п. 3./ $\left.\mathrm{M}^{3}\right)$ спостерігався 2 вересня. Статистично визначений сезон пилкування становив 44 доби, а всього п. з. амброзії реєстрували у повітрі міста упродовж 102 діб.

Таблиия 2

Календар пилкування основних представників алергенної аеропалінофлори м. Дніпропетровськ (2010 р.)

\begin{tabular}{|c|c|c|c|c|c|c|c|c|c|c|c|c|c|c|c|c|c|c|c|c|c|c|c|}
\hline \multirow{2}{*}{ № } & \multirow{2}{*}{ Назва } & \multicolumn{2}{|c|}{ Березень } & \multicolumn{3}{|c|}{ Квітень } & \multicolumn{3}{|c|}{ Травень } & \multicolumn{3}{|c|}{ Червень } & \multicolumn{3}{|c|}{ Липень } & \multicolumn{3}{|c|}{ Серпень } & \multicolumn{3}{|c|}{ Вересень } & \multicolumn{2}{|c|}{ Жовтень } \\
\hline & & II & III & $\mathrm{I}$ & II & III & $\mathrm{I}$ & II & III & I & II & III & $\mathrm{I}$ & II & III & I & II & III & I & II & III & $\mathrm{I}$ & II \\
\hline 1 & Клен & - & - & - & + & - & - & - & - & - & - & - & - & - & - & - & - & - & - & - & - & - & - \\
\hline 2 & В'яз & - & - & - & + & - & - & - & - & - & - & - & - & - & - & - & - & - & - & - & - & - & - \\
\hline 3 & Береза & - & - & - & $+11+$ & ++ & - & - & - & - & - & - & - & - & - & - & - & - & - & - & - & - & - \\
\hline 4 & Дуб & - & - & - & - & - & ++ & + & - & - & - & - & - & - & - & - & - & - & - & - & - & - & - \\
\hline 5 & Кропива & - & - & - & - & - & - & - & - & - & - & - & - & ++ & - & - & + & + & - & - & - & - & - \\
\hline 6 & $\begin{array}{l}\text { Айстрові } \\
\text { (без Ambrosia } \\
\text { та Artemisia) }\end{array}$ & - & - & - & - & - & - & - & - & - & - & - & - & - & - & - & H & $+1+$ & + & + & - & - & - \\
\hline 7 & Злакові трави & - & - & - & - & - & - & + & + & - & 1 & $+1+$ & ++ & $+1+$ & + & - & + & + & - & - & - & - & - \\
\hline 8 & Полин & - & - & - & - & - & - & - & - & - & - & - & - & - & $+1+$ & $+1+$ & + & ++ & + & ++ & + & + & - \\
\hline 9 & Амброзія & - & - & - & - & - & - & - & - & - & - & - & - & - & - & - & $+1+$ & $+1+$ & $+1+$ & $+1+$ & $+1+$ & ++ & + \\
\hline 10 & Лобода & - & - & - & - & - & - & - & - & - & - & - & - & - & - & - & ++ & $+1+$ & ++ & + & - & - & - \\
\hline
\end{tabular}

Примітка: «-» - слабка палінація, «+» - понижена активність, «++» - помірна активність, «+++» - висока активність, «++++» - найвища активність (піковий період).

За наведеними результатами аеропалінологічного моніторингу складено сучасний календар пилкування аероалергенних рослин м. Дніпропетровськ (див. табл. 2). У ньому представлено 10 аеропалінологічних категорій рослин, п. з. яких найчастіше реєструються в атмосфері
Дніпропетровська та мають виражену алергенність, доведену клінічно для української популяції (Rodinkova and Kremenska, 2011). Узагальнюючи результати дослідження, бачимо, що найгіршими для пацієнтів є II та III декади квітня, асоційовані з пилкуванням берези, та 
І декада травня, коли інтенсивно пилкує дуб. Улітку клінічно важливими для пацієнтів, чутливих до пилку злаків, $є$ III декада червня, I та II декади липня. Пацієнти, чутливі до п. з. полину та амброзії (пилок цих рослин відомий здатністю викликати перехресні реакції (Sofiev and Bergmann, 2013)), потерпатимуть від полінозу, викликаного здебільшого п. 3. Artemisia spp. 3 III декади липня, а 3 II декади серпня й до кінця вересня превалюючим алергенним чинником атмосфери Дніпропетровська можуть бути п. з. амброзії. У цей же період, як зазначено вище, сезонну алергію можуть зумовлювати також п. 3. інших представників родини айстрових. Наведений календар пилкування алергенних рослин рекомендується до уваги лікарів-алергологів та їх пацієнтів як основа коректної діагностики та профілактики сезонної алергії у певний період року. За його допомогою можна не лише корегувати діагностику та лікування алергологічних станів поза сезоном активності рослин, а й попереджувати настання алергійної симптоматики у сенсибілізованих осіб перед цвітінням того чи іншого продуцента алергійного пилку.

\section{Висновки}

Таким чином, у Дніпропетровську не спостерігаються класичні весняна та літньо-осіння хвилі пилкування, виражені в інших містах України. У місті добре виражена літньо-осіння хвиля $з$ превалюючим інтенсивним пилкуванням амброзії з надвисокими піками та загальною масивністю, що перевищує 60\% загальної кількості пилку, зібраного у місті упродовж сезону.

Найгіршими для пацієнтів є II та III декади квітня, асоційовані з пилкуванням берези, та I декада травня, коли інтенсивно пилкує дуб. Улітку клінічно важливими для пацієнтів, чутливих до пилку злаків, є III декада червня, I та II декади липня. Пацієнти, чутливі до п. з. полину та амброзії, потерпатимуть від полінозу, викликаного здебільшого п. 3. Artemisia, у III декаду липня та I декаду серпня, а 3 початком серпня й до кінця вересня превалюючим алергенним чинником атмосфери Дніпропетровська $є$ пилок амброзії: у цей період концентрації ії п. 3. перевищують поріг у 15 п. 3./ $\mathrm{M}^{3}$.

Найінтенсивішну палінацію у Дніпропетровську, крім амброзії, мають рід щириця / родина лободові, кропива дводомна, полин і рослини родини айстрових.

Наведений календар пилкування алергенних рослин рекомендовано до уваги лікарів-алергологів та їх пацієнтів для діагностики та профілактики сезонної алергії. Календар, через поступову зміну факторів довкілля, що впливають на розповсюдження природних алергенів, потребує подальшого оновлення.

\section{Бібліографічні посилання}

Bicakci, A., Altunogu, M., Aybeke, M., Sapan, N, Erkan, P., 2010. The concentration of atmospheric pollen of Edrine, Turkey. Allergy 65 (Suppl. 92), 422-423.

Buters, J., Galán, C., Thibaudon, M., Smith, M., 2012. Hialine project: Allergen release from pollen across Europe. Alergologia Immunologia 9(2-3), 147.

Castro, L., Barber, D., Lombardero, M., 2011. Isoallergen profile recognition by the $\mathrm{mAb}$ used an ELISA for Bet $\mathrm{v} 1$ quantitation. Allergy 66(Suppl. 94), 331-332.
Deaka, A., Makrab, L., Matyasovszkyc, I., Csepeb, Z., Muladia, B., 2013. Climate sensitivity of allergenic taxa in Central Europe associated with new climate change related forces. Science of The Total Environment 442(1), 36-47.

Della Torre, E., Limonta, A., Della Torre, F., 2010. Which ornamental plants would be better? Allergy 65(Suppl. 92), 423-424.

EAN. European Pollen Information, 2012. Retrieved from URL: https://ean.polleninfo.eu/Ean/en/home.

Fernándes-González, D., Rodrigues-Rajo, F., González-Parrado, Z., Arias, S., Valencia-Barrera, R., Moreno-Grau, S., Asturias, J., Suárez-Cervera, M., 2008. Relationship between Poaceae pollen counts and the quantification of the Lol $\mathrm{p} 1$ allergen atmospheric content. Allergy 63(Suppl. 88), 548-549.

Frenz, D.A., 1995. Making sense of the numbers: What to do with a pollen count once you have one. A The Pollen Monitor: Newsletter of multidata, Inc 1(11), 3.

Galán, C.S., Cariñanos, P.G., Purificación, A.T., Domínguez, E.V., 2007. Spanish Aerobiology Network (REA): Management and quality manual. Servicio de publicaciones de la Universidad de Córdoba.

Gálan, C., Domingues, V.E., 2012. Effect of climate change on plant distribution and phenology in the Iberian Peninsula. Alergologia Immunologia 9(2-3), 101-103.

Grewling, Ł, Jackowiak, B., Nowak, M., Uruska, A., Smith, M., 2012. Variations and trends of birch pollen seasons during 15 years (1996-2010) in relation to weather conditions in Poznań (western Poland). Grana 51(4), 280-292.

Hilaire, D., Rotach, M., Clot, B., 2012. Building models for daily pollen concentrations. Aerobiologia 28(4), 499-513.

Jager, S., Berger, U., Smith, M., 2012. European Network, new challenges. Alergologia Immunologia 9(2-3), 69-71.

Kagen, S., Lewis, H., Walter, L.E., 2004. Aeroallergen Photo Library of North America Transcribed, DePass Media Productions, Appleton, Wisconsin.

Kizilpinar, I., Dogan, C., Artac, H., Gokturk, B., Keles, S., Reisli, I., 2010. The effects of meteorological parameters on the pollen amounts of Poaceae, Asteraceae, Chenopodiaceae / Amaranthaceae, Rumex and Plantago taxons determined in Konya city atmosphere in 2009. Allergy 65(Suppl. 92), 429-430.

Kuprijanova, L.A., Aleshina, L.A., 1972. Pyl'ca i spory rastenij flory Evropejskoj chasti SSSR. Tom 1 (Pollen and spores of plants Flora of the European part of the USSR. Vol. 1). Moscow, Nauka (in Russian).

Kuprijanova, L.A., Aleshina, L.A., 1978. Pyl'ca dvudol'nyh rastenij flory Evropejskoj chasti SSSR. 2. (Pollen of Dicot plants Flora of the European part of the USSR. 2). Leningrad, Nauka (in Russian).

Lanzoni, C., 2009. Since 1932. Practical Materials of the 9th European Course on Basic Aerobiology, 2-9th September 2009, Evora, Portugal, p. 6.

Melgar, M., Trigo, M., Recio, M., Docampo, S., GarcíaSánchez, J., Cabezudo, B., 2012. Atmospheric pollen dynamics in Münster, north-western Germany: A three-year study (2004-2006). Aerobiologia 28(4), 423-434.

Molina, R., Manzano, J., Rodríguez, S., Garijo, A., Palacios, I., 2013. Influence of environmental factors on measureements with Hirst spore traps. Grana, Jan, DOI:10.1080/00173134.2012.718359

Mozo, H.G. (ed.), 2011. Minimum requirements to manage aerobiological monitoring stations included in a national network involved in the EAN. International Aerobiology Newsletter 71, 1-2.

Myszkowska, D., Jenner, B., Stępalska, D., Czarnobilska, E., 2011. The pollen season dynamics and the relationship among some season parameters (start, end, annual total, season phases) in Kraków, Poland, 1991-2008. Aeribiologia 27(3), 229-238.

Oh, J., Lee, H., Kang, I., Cheong, J., Kim, S., Park, K., Kook, M., Kim, B., 2010. The development of pollen calendar and 
map of Korea Allergy 65(Suppl. 92), 423.

Piotrowska, K., 2012. Forecasting the Poaceae pollen season in eastern Poland. Grana 51(4), 263-269.

Piotrowska, K., Kubik-Komar, A., 2012. The effect of meteorological factors on airborne Betula pollen concentrations in Lublin (Poland). Aerobiologia 28, 467-479.

Prikhodko, O., 2012. Aeropalynological situation in regional centers of Zaporizhska oblast during ragweed pollen season [Aeropalinologichna sytuacija po rajcentrah Zaporiz'koi' oblasti v period cvitinnja ambrozii']. Visn. Zaporizhzhya Nac. Univ. 2, 169-171 (in Ukrainian).

Puhlik, B.M., Ditjatkvs'ka, Y.M., Goguns'ka, I.V., Holodenko, T.J., 2012. Issues of prevalence and cost-effectiveness of treatment of allergic respiratory diseases in Ukraine [Pitannja poshirenosti ta ekonomichnoï efektivnosti likuvannja alergijnih zahvorjuvan' organiv dihannja v Ukraïni]. Klinichna Imunologija, Alergologija, Infektologija (Clinical Immunology, Allergology, Infectology) 2, 5-7 (in Ukrainian).

Rapiejko, P., Lipiec, A., 2012. Pollen information systems for patients. Alergologia Immunologia 9(2-3), 123-124.

Rodinkova, V.V., Kremenska, L.V., 2011. The patterns of trees pollination in Vinnitsa: Trends of 1999-2000 and 20092010, as markers of climate change impacting public health [Harakter pilkuvannja derev u Vinnici: tendenciï 1999-2000 ta 2009-2010 rokiv jak markeri klimatichnih zmin, shho majut' vpliv na zdorov'ja naselennja]. Biomedical and Biosocial Anthropology 16, 59-64 (in Ukrainian).
Rodinkova, V., 2012. Pollen calendar of major allergens of Vinnitsa city: What you need to know to protect yourself from hay fever [Kalendar pilkuvannja osnovnih alergeniv $u$ Vinnici: Shho treba znati, shhob sebe vid polinozu zahishhati]. Novyny Medycyny ta Farmacii' (News of Medicine and Pharmacy) 15(425), 18-20 (in Ukrainian).

Rodinkova, V., Stremedlovsky, B., Kremenska, L., Palamarchuk, O., Bilous, O., DuBuske, L., Helman, E., 2012. Correlation between the airborne pollen counts and symptoms of allergic patients in Vinnitsa, Ukraine. Allergy 67 (Suppl. 96), 243.

Sofiev, M., Bergmann, K-C. (eds.), 2013. Allergenic pollen: A review of the production, release, distribution and health impacts. Springer Science + Bisness Media Dordrecht.

Sulmont, G., 2008. The pollen content of the air identification key [Electronic Resource]: Reseau National de Surveillance Aerobiologique. 1 CD-ROM. Production: Julie Collet. Studio Bouquet. Saint Etienne (France).

Tormo-Molina, R., Gonzalo-Garijo, M., Silva-Palacios, I., Moreno-Corchero, A., Muñoz-Rodriguez, A., 2008. Information about airborne pollen concentrations and pollen forecast using SMS (Short Messaging Service). Allergy 63(Suppl. 88), 548.

Weger, de L.A., Beerthuizen, T., Gast-Strookman, J.M., Dirk, T., Van der Plas, Terreehorst, I., Hiemstra, P., Sont, J., 2011. Difference in symptom severity between early and late grass pollen season in patients with seasonal allergic rhinitis. Clinical and Translational Allergy 1, 18. 